\title{
タイヤコードの疲労に関する研究"
}

（第 1 報） 綿コード及びレイヨンコードの届曲疲労試験

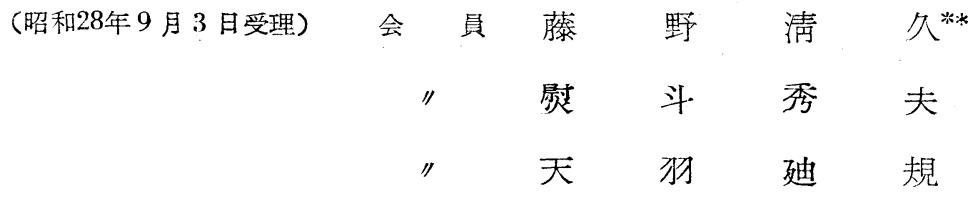

\section{硈 究目的}

（1）レイヨンコードと綿コードとの屈曲疲労を比較する。

(2) 屈曲疲労試験機の性能をしらべる。

\section{砶 究 結 果}

（1）レイヨンコードの疲労寿命は綿コードに比較して、屈曲程度、屈曲と伸蜄との組合せ制合、荷重の大きさ 等の試験条件によつて著しい影響を受ける。条件によつて綿コードよりすぐれている場合与出り不良の場合も女る が、レイョンコードに対して特に悪い条件は、张力と曲げの曲率が共に大きい場合である。

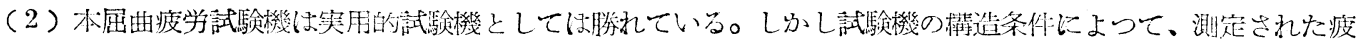

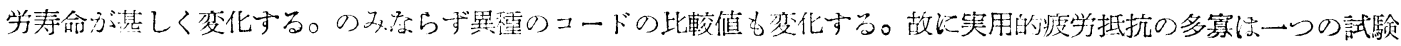
条件の々では判断出来ない。

\section{1. 緒}

\section{言}

タイヤコードの咲用的疲労茑験機としてU.S. Rubber Conpany $\sigma$ Cord Fatigue Tester, The Firestone Snapcycle machine, Good Year Machine, Good rich Vibrator 等は比較的良く知られ、それらの比較検馀小 Venable によつて詳細に行われたが、標準試験機として 採用される段皆には到つていない。その後新らしい考案 になる振動敨良型、欧縮型、屈曲型等が発表されている が、いずれが最も適切な価を与えるか未だ不明である。 もとよりタイヤの中で特殊な環境の下に、各種の作用を 受けているコードの疲労を、簡単な一種の試験機によつ て評佰しようとするのは困難なことであるが、その中で Budd の発表している屈曲型の疲労試験機はコードに対 すっ作用がタイヤ中で实際コードが受ける作用と比較的 近似しているように思われる。しかしこれは試験機の構 造条件及び試験条件を各種変化することが出来、その各 場合によつてコードに与える作用が異なるので、測定さ れる疲労寿命も当然变化する。
本研究ではこの種の屈曲型疲労試験機について棈造条 件と試験条件とを色々変化してコードに異なつた作用を 与え、綿コードとレイヨンコードに対してその疲労寿命 を測定し、两コードの疲学特性を調查すると同時に届曲 型晟労試験機の性能をしらべた。

\section{2. 試驗機の構造とコードの受ける作用}

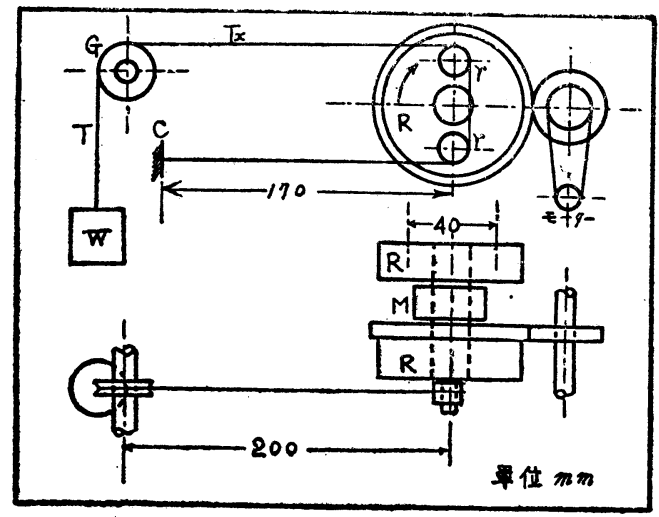

（第1図）試験機の図

* A Study on Fatigue of Tire-Cords.

(1st Report) Beriding Fatigue Test of Cotton and Rayon-Cords.

** K. Fujino, Member. 京都大学工学部

H. Noshi, " 京都工藝纎維大学

M. Amau, " 
試験機の構造略区第 1 四に示す。Budd の屈曲型疲 労試験機をやや改造したるのである。回転体 $R$ に屈曲 用小ャーラ $r r$ をとりつけ、これが小軸の上で自由に回 転するようになつている。（Budd 試験機では $r r$ の小 ローラを積極回転せしめている)コードは図の如くとり つけ、一端を固定、一端にガイドローラ $G$ 経て重垂 $W$ を吊り下げる。 $G$ を固定し、コードは $G$ 上を滑るよ うにした。 $G R$ の距離 (中心間) は $20 \mathrm{~cm}, \quad r r$ 距離 (中心問) は $4 \mathrm{~cm}$ である。

屈曲ローラは大中小の 3 種を使用した。これを第 1 表 （第 1 表） 屈曲口 - ラ

\begin{tabular}{|c|c|c|c|}
\hline & $\begin{array}{c}\text { ローラ直径 } \\
r \mathrm{~mm}\end{array}$ & $\begin{array}{c}\text { ローラ輔直径 } \\
r^{\prime} \mathrm{mm}\end{array}$ & $\mu^{\prime}-\frac{r^{\prime}}{r}$ \\
\hline 大 & 20 & 7 & 0.042 \\
\hline 中 & 14 & 4 & 0.034 \\
\hline 小 & 7 & 4 & 0.064 \\
\hline
\end{tabular}

に示す。 $R$ の回転は夭゚方向としたが逆転も可能であ る。回転速度は $100 \sim 500$ r.p.m，の籆囲で変化するよ うにした。支え $M$ の軸受けにはボールベアリングを使 用し、 $R$ の回転を確実にした。

この言式験機は $R$ の回転によつて 屈曲小ローラがコー ドに折り曲げを与えるので、通常屈曲式といわれている がコードは単純な屈曲作用のみを受けるのではない。

(1) コードの伸唇歪

$r r$ の距離が十分小さく、GRの距離に比較して無視出 来る程度であれば、 $R$ の回転により $\operatorname{rr} C$ の距離は変 化しないが、杖試験機の寸法ではその長さが最大約 0.5 \%変化する。( $G r r C$ の最大は $r r$ が水平になつた位羁 で生ずる) しかるに $G$ はュードの引涱りに対して固定 と同様に作用するから (後述) コードに約 $0.5 \%$ の伸張 需を生じる。この霜は $r r$ と $G R$ との距離の比によつて 自由に变えることが出来るが、本失験では歪 $0.5 \%$ の場 合以ついてのみ行つ灷。

\section{（2）重鍾によつてコードに生じる㲀力}

ガイドローラ $G$ を固定する場合と自由に回転する埸 合とでは、同じ禹錘を使用してもコードに生じる张力 $T_{x}$ は異なる。本試駼機では $G$ を固定したから重䠊 $W$

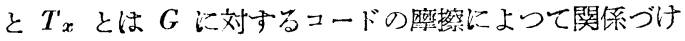
られる。故以

$$
W=T=T_{x} \cdot e^{\mu \theta}
$$

$\mu$ は $G$ とコードの杪擦係数、 $\theta$ は $G$ とコードとの接 触角で $\pi / 2$ である。屈曲作用によつてコードが湖び $T_{x}$ が減少して $T_{x}<W / e^{\mu \theta}$ となれば。 $W$ は縻擦比打勝つ
て滑り怙りるから、GR 部分の最小張力は常飞一定で $W / e^{\mu \theta}$ である。な岕この $G R$ の部分は試料ニードの中 で最大張力を受ける部分である。

$R$ の回転によるコードの伸張及び屆曲ローラを回転せ しめるための張力によつて $T_{x}$ が增加してす、 $T_{x} \leqq$ $W \cdot e^{\mu \theta}$ であれば $W$ は引き山げられない。即ち引涱りに 対しては固定と同椂である。

本装䍗ではコードの歪が小さく既力の増加が少ないか ら、 $W=0.5 \mathrm{~kg}$ 以上であれば $W$ 以引きトげられなかつ 火。

$e^{\mu \theta}$ の測定值は常態でレイョンシード 1.87 , 綿コード 1.97であつた。但し $\mu$ は静磨擦係数である。故に同じ 重鍕でるレイヨンコードと綿コードとの張力はやや異な る。

(3) 屈曲ローラの作用

$G R$ の距離が $r r$ に比較して十分大でコードと屈曲ロー ラが全然滑らないものとすれば、 $R$ と $r$ との回転の関係 は

$$
n=\frac{R}{r} N \cdot \cos \theta
$$

$n$ は $r$ の回転速度、 $N$ は $R$ の回転速度、 $\theta$ は $R$ の 回転角、 $R, r$ 世同名称ローラの半径を示す。

故に屈曲小ローラを積極回転してローラとコードとの 滑りを完全になくするためには、屈曲小ッーラを変速回 転しなければならない。しかるに Budd の試験機では積 極等速回転であるからコードとの間飞滑りを生じ、更に 滑りのために張力の変化子生じるわけである。

本試験機の如くローラを消極回転せしめるものでは、 $\mu^{\prime} r^{\prime} / r\left(\mu^{\prime}\right.$ は屈曲ローラとその軸々の杽擦係数、 $r^{\prime}$ は軸 の半径) が小で安れば、トーラはコードによつて回転せ しめられる。しかしコードとローラとの接触角が小なる

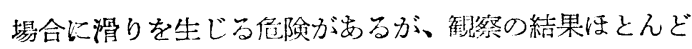
滑りは認められなからた。この場合コードがローラを回 転ぬしめるからコードに毉張側と弛緩側とを生じ、この 張力の差はローラとコードとの接触角の変化によつて增 隇する。従つてコードはッーラによる折り曲げと岡時 に、張力の繰返しも受ける。

\section{3. 害}

驗

変化せしむべき試駼機の構造条件及び試験条件は種々 岁るが、その中で次のものについて实験をした。

（1）屈曲ローラの大きさを変化した場合

（2）硒曲ローラを固定して摩擦による場合

（3）支え $M$ の軸受けにボールベアリングを使用し ない場合 
（4）回転速度を変化した場合

（5）回転を逆転にした場合

（6）糸の太さを変化した場合

初めの 3 条件はコードの疲労特質の研究と試験機の性 能試験とを兼ねたものであり、後の 3 条件は主として試 験機の性能試験である。これらの各場合以ついて荷重と 疲労寿命の関係を測定した。試料コードの主な特性を第 2 表に示す。同表の上撚数はコードの単位長さ当りのも

(第 2 表) 試 料 コ - ド

\begin{tabular}{|c|c|c|c|c|c|c|c|c|}
\hline 種 類 & 構 造 & $\begin{array}{l}\text { 上 撚 } \\
\text { t. p. m. }\end{array}$ & $\begin{array}{l}\text { 中 撚 } \\
\text { t.p. m. }\end{array}$ & $\begin{array}{l}\text { 下 撚 } \\
\text { t.p. m. }\end{array}$ & 強 kg & 伸 \% & $\begin{array}{c}\text { 結節強力 } \\
\mathrm{kg}\end{array}$ & $\begin{array}{c}\text { コード } \\
\text { ゲージ } \\
\mathrm{mm}\end{array}$ \\
\hline レイョン & $1,650 \times 2$ & 450 & 一 & 420 & 8 & 22 & 3.9 & 0.82 \\
\hline 綿 & $22 / 5 / 3$ & 380 & 620 & 一 & 8.9 & 19 & 6 & 0.84 \\
\hline
\end{tabular}

屈曲ローラを 3 種使用した場合（ローラ及びローラ軸 は第 1 表に示す）の荷重と疲労寿命の関係を第 2 図( イョン)、第 3 図 (綿) に示す。荷重と疲労寿命（繰返 回数 $N$ の対数)の関䋆は荷重が大きい範囲ではほぼ直 線状をなす。即ち

$$
W=A-B \log _{10} N
$$

$W$ は重鏵、 $A, B$ は常数、Nは町断までの繰返回数で ある。但し $W$ のかわりに $T_{x}$ を用いると常数は異なつ
のであり、中然(綿コード) 及で下撚(レイヨンコード) は上撚を全部除去した時の単位長さ当りのものである。 疲労試験及び引張り試験時の温度は $12^{\circ} \pm 2^{\circ} \mathrm{C}$, 湿度は $61 \pm 1 \%$ \%安り、回転方向は矢の方向（第1図）、回転 速度 350 r.p. m, である。

(1)・倔曲ローラの大きさの影響

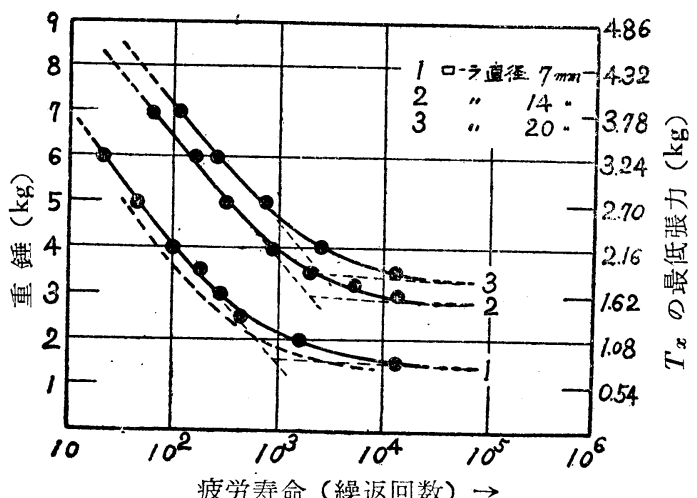

(第 2 図) レイヨンコードの疲労寿命に対する屈曲 ローラの大きさの影㦘

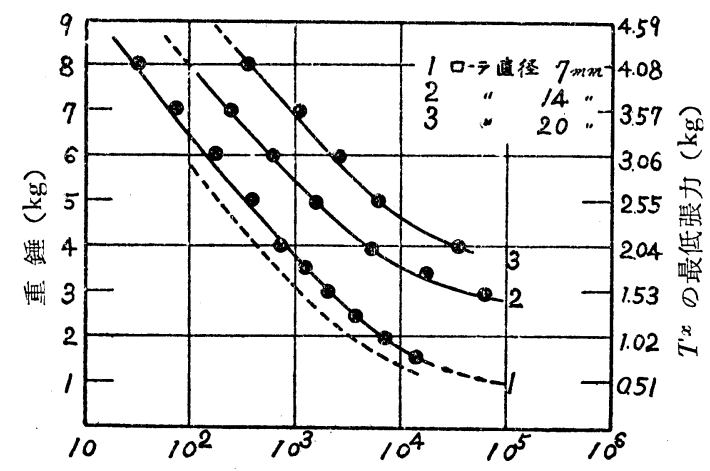

疲学寿命 (繰返回数) $\rightarrow$

(第 3 図) 綿コードの疲労寿命に対する屈曲ローラ の大きさの影響
線部分と大荷重の斜の直線部分との交点を求め、仮に疲 労限界を表わ也ば第 3 表の如くになる。

(第 3 表)

\begin{tabular}{|c|c|c|c|}
\hline & \multicolumn{3}{|c|}{$\begin{array}{c}\text { 屈曲ローラの直径 } \\
\mathrm{mm}\end{array}$} \\
\hline & 7 & 14 & 20 \\
\hline レイヨンコード疲労限界 応力 $\mathrm{g} / \mathrm{d}$ & 0.25 & 0.5 & 0.6 \\
\hline 同上に対する最小繰返回数 & 990 & 2,140 & 2,820 \\
\hline 綿 コード疲労直線 $\left\{\begin{array}{l}A \\
B\end{array}\right.$ & $\begin{array}{r}11.73 \\
2.66\end{array}$ & $\begin{array}{r}13.35 \\
2.66\end{array}$ & $\begin{array}{r}14.98 \\
2.66\end{array}$ \\
\hline レイヨンコード疲労直線 $\left\{\begin{array}{l}\mathrm{A} \\
\mathrm{P}\end{array}\right.$ & $\begin{array}{l}9.45 \\
2.65\end{array}$ & $\begin{array}{r}11.75 \\
2.65\end{array}$ & $\begin{array}{r}12.45 \\
2.65\end{array}$ \\
\hline
\end{tabular}

属曲ローラの径が増加ず程、疲学限界応力が増加 する。屈曲ローラの径が変つた場合、綿、レイヨンいず れも疲労直線部分の傾斜 $B$ は変化せず、 $A$ のみが変 化して、疲労限界が増加する。しかし綿コードとレイョ ンコードとの $A$ の堌加割合は異なる。

この垁験範囲で綿コードの $A$ の熄加はローラ直径の 増加にほぼ比例するが、レイヨンコードの場合ばーラ が小さい程增加が大である。即ちレイヨンコードは属曲 ローラが小なる時、ローラ径の影響が大きい。それぞれ の $A, B$ 值を第 3 表に示した。

寒用試験機で属曲ローラの選定に当つては、試験の速 度化をはかるため、ローラの径を小にすることはレイヨ ンコードに対しては過小の洒を、綿コードに対しては過 大の価を示すことになる。綿及びレイヨンコードの $B$ がほぼ等しいのはこの試験条件によっ偶然の一致です り、次に述べる如く朝受にボールベアリングを使用しな い場合には明らかに相違する。

（2）屈曲摩祭の場合 
Budd は回転ローラを固定し完全䐴繁を行つた場合 と、屈曲ローラ定積極回転して場合との疲労寿命の測定 值は殆えど闹一であつたと報告しているが、前述の如く この積極式回埲では常に一定量の䬿耗を生じるから、こ のような結果を示したのであろう。

本武験機の如くローラが完全に回転しているものでは 当然摩耗の有鶖による疲学寿命の变化が想される。こ

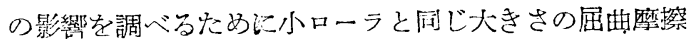
軸を用いその測定結果を第4怄示した。(点線は口ー 亏回轱の場合)

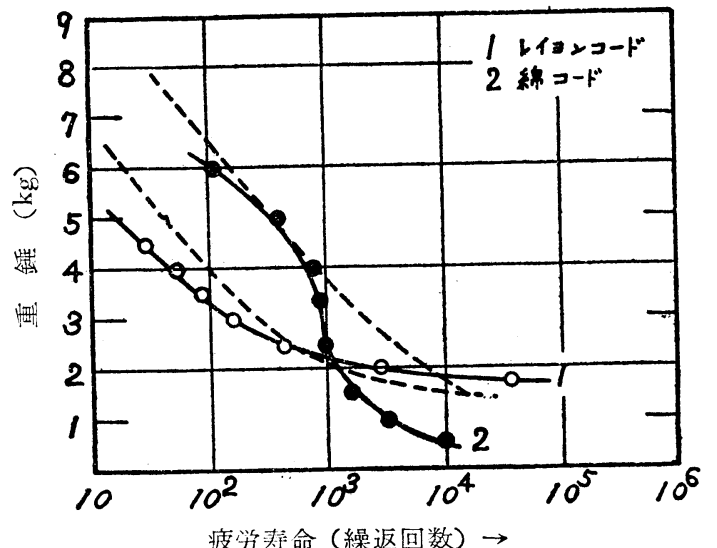

（第4図）屈曲摩擦による疲労

レイヨンコードー荷車の大なる場合、明らかに磨檫疲 学寿命は小だ女らが、荷重が小さく疲学限界近くなると

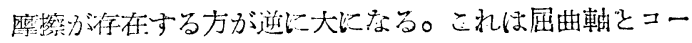
ドとの長特聞の腹摖のためその部分に発熱し、レイヨン コードが故燥するためと思われる。疲労直線部の傾斜は Fーラ回転の垻命とほぼ同一で女る。

綿コードー摩摖の場合と回忶の場合とは卙だしく相堂 する。摩撚の場命荷禹対 $\log N$ の関係は $\mathrm{S}$ 字型となり。 疲労寿命はいずれも回転の憬合より小で女るが、少車 5 $\mathrm{kg}$ の辺では磨擦の存在する境合と必い場合との雨者が棌 とえど一致している。

これは綿コードの毛羽による磨耗の特殊性を示するの と思われる。

爻摩擦の女る場会小荷重以対して綿コードが著しく疫 労寿命が小さくなることは注目すべきである。

(3) 支え $M$ 部の朝受にボールベアリングを使用し ない場合

以上の実験は支え $M$ 部の軹受（第1図）にボールベ アリングを使用して $R$ の回転を確実にしたが、ボール ベアリングを使用垉ず通常のメタル軸受を使用した場合 の奏験結果を第 5 区示す。（屈曲ローラは小と大）こ

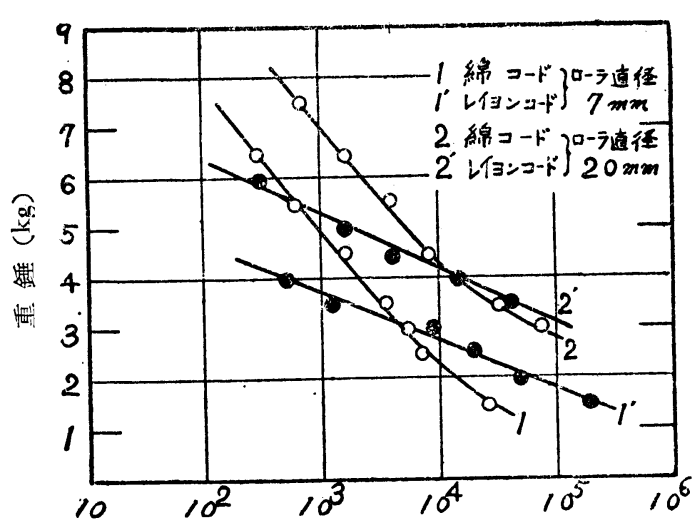

疲労寿命 (繰返回数) $\rightarrow$

(第 5 図)

レイヨン及び綿コードの疲労寿命に対する屈曲 ローラの大ささの影響（軸受けにボールベアリ ングを使用しない場合)

の場合軸受にややがたが女り、Rの回転によらコードの 歪が小になる。これは不正確な試験機によら測定結果で あつてそれ自身の意味は少ないが、試験機が漂耗した場 合の誤差の予想と $R$ の回転によるコードの歪の少ない 場合の予想になる。いずれる疲学寿命は葚しく堌加して いる。

一例を示せばレイヨンコード重錘 $3 \mathrm{~kg}$ の場合、ペアリ ングのある時300〜400回で切断するものが、ベアリング のない時は約 10,000 回て切断する。綿コード重㳻 $3 \mathrm{~kg}$ でベアリングのある時 $1,000 〜 2,000$ 回で戓断するが、ベ アリング のない時 7,000〜8,000 回で戓断するという大 きな変化を示す。屈曲程度は同じであるから軸受の不正 が如何に大きい誤差を生じるかがわかる。ローラの大き さによる变化の関係はボールベアリングを使用した場合 とほぼ近似しているが、変化程度は相当に小である。綿 コード疲労滇線部の傾斜 $B$ はベアリングを使用した埸 合とほぼ等しいぶ、レイヨンコードでばベリンン゙を使 用したものより小になり荷車の依存性が大となる。

\section{(4) 回転僬庭の影啫}

ガイドローラを固定し、重旅を振動せしめない本試験

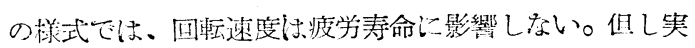

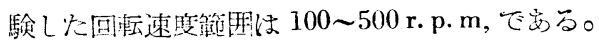

測定結果を第子㤗のガイドローラ固定の欄に示す。し

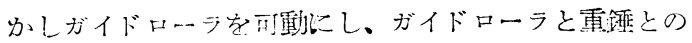

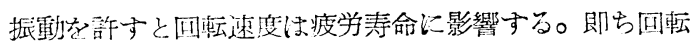
数大なる埸会ガイドローラと黄錘とはほとんど振動しな いが、回転数小なる場合は十分に振動しコードに働く作 用が異なるためである。測定結果を第4表カイドローラ 
（第 4 表）疲労寿命に対する回転速度の影響

\begin{tabular}{|c|c|c|c|c|c|c|c|c|}
\hline \multirow[b]{3}{*}{ 重錘 kg } & \multicolumn{4}{|c|}{ ガイドローラ固定 } & \multicolumn{4}{|c|}{ ガイドローラ可動 } \\
\hline & \multicolumn{2}{|c|}{ レイョンコード } & \multicolumn{2}{|c|}{ 綿 コ一ド } & \multicolumn{2}{|c|}{ レイヨンコード } & \multicolumn{2}{|c|}{ 綿 コ一ド } \\
\hline & $\begin{array}{c}100 \\
\text { r. p. m. }\end{array}$ & 500 & 100 & 500 & 100 & 500 & 100 & 500 \\
\hline 2.5 & 468 & 437 & 一 & 一 & 500 & 490 & - & 一 \\
\hline 3 & 298 & 280 & 2,170 & 1,990 & 178 & 282 & 1,621 & 1,870 \\
\hline 3.5 & 184 & 180 & 1,280 & 1,310 & 80 & 170 & 578 & 1,430 \\
\hline 4 & - & - & 940 & 998 & 一 & - & 330 & 810 \\
\hline
\end{tabular}

ぬる。同じ den. 当りの荷重に対 する疲学寿命はほぼ糸の太さに比 例して減少し、（眓の右.上）疼学 直線部は糸が太くなるにつれて臣 ぼ平行に移動寸る。しかしこの関 係は糸の種類によつて変化すっか ら、この試験において太さの異な るコードの疲学寿命の比較には注 意を姴する。

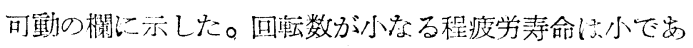
るがその潣少程度は荷重飞よつて異なる。

(5) 逆転の影響

上述の垁験では総べて $R$ を矢の方向（第1园）に回 転したから屈曲ローラの回転に対して $T_{x}$ は等张側であ る。

これを逆転せしめると $T_{x}$ は遅緩側になる。故に迤緩 側の最低張力が $W / e^{\mu \theta}$ になるから全体の張力分布が正

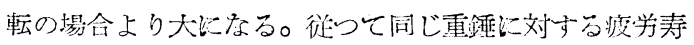
命の測定値は当然小になるはずである。レイヨンコード と綿コードについて小ローラで測定した結果を第 2,3 図に点線で示した。疲学值線部は平行に移動し、いずれ も疲労寿命は小になるが、綿コードの減少程㡲はレイヨ ンコードよりやや多い。

(6) 系の太さの影響

同じ屈曲を与えると糸が太い程外側の可德り歪と内側

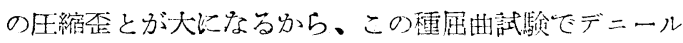
当りの荷重が等しい場合、太い糸程、瘦学寿命が小に示さ れることは予想される。レイヨンコード原糸( 1,650 den.) を $1,2,3,4$ 本合撚したもの（然常謷はいずれも $82 / \mathrm{cm}$ ) についての矢験結果第6脑に示す。(屈曲ローラは小)

区に示した重錘の重品 $1,650 \times 2 \mathrm{den}$. 当りのもので

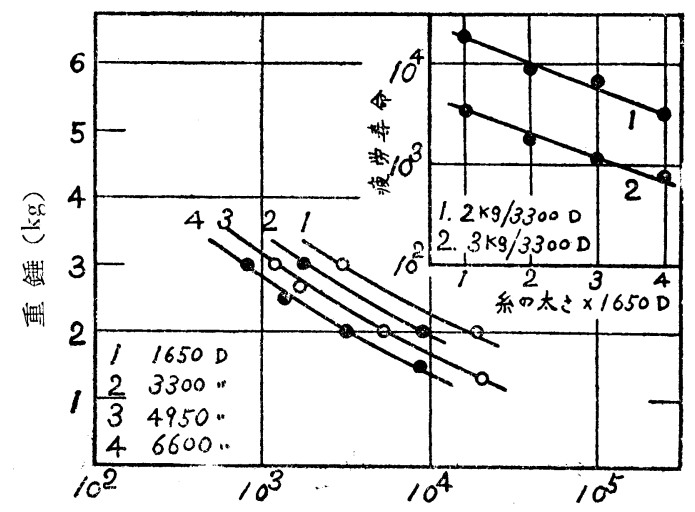

疲労寿命 (繰返回数) $\rightarrow$

（第6図）屈曲疲学に対する系の太さの影響
（7）綿ニーードとレイヨンコードとの疫労毒命の比較 以上湘定した各理条件について、㠿一荷重に刘する綿 コードとレイヨンコードとの疲労寿命の比を符 7 脑示

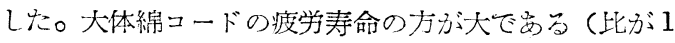

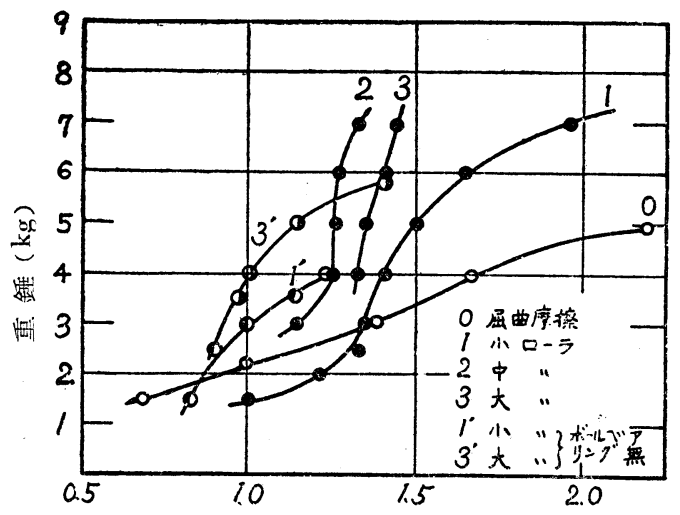

(綿コードの疲労寿命)/(レイヨンコードの疲労寿命) (第 7 図)

綿コードとレイヨンコードの疲学寿命の比較

より大が、その比は屈由ローラの大きさ、荷重の大き さ等によつて0.7〜2.5の公範国にわたつて変化する。こ の中のどれかが実際值と一致するはずであるが、この種 試験だけではその決定は出来ない。故に一条件の疲学試 験によつて実用的疲労抵抗の大小を判断することは甚代 仜険である。

凶には同じ重鉏に対する $\log N$ の比を示したが、そ の場合綿コードの最低張力 $\left(T_{x}\right)$ はレイヨンコードのそ れよりやや小であるから、同じ $T_{x}$ に対する比を示せば 比の值は第 7 困のものよりやや小になる。

図から分るように一般に大なる張力受けながら曲率 の大なる屈曲を受けるとレイヨンコードは綿コードより 著しく疲労に弱い。曲げの击率が小になるに従つて次第 に綿コードに接近する。しかし張力がななる場合は曲げ の曲率分大きくとも綿コードより強くなることもある。 又小荷重で䐴察の条件が加わればレイヨンコードは綿コ ードより多疲労に耐完る。 


\section{4. 屈曲疲勞試驗機の批判}

この型の屈曲式疫労圾験は各種の作用を組食ゼた実際 的な疲学の試験として都命のよいものであるが、試験機 のいかなる条件の測定結果がタイヤの些祭寿命と比例す るかということは本試殷げけでは不明である。ローラの 大きさ、歪と屈曲の組合せ、屈曲ローラの摩攃、荷重等 の各種条件の適当な組合せによつて芙際値に近いわのが 得られるはずである。がその決定は容易でない。

取り报い上チ子ック切れのないこと、屈曲、他張、磁 擦等各種の組合せの試験を行えるという利点のために告 用的試験機としては都合がよい。他方屈曲ローラの回 転、又はコードの摩撚のための発熱が影響すること、太 さの異なつたコードの比較が困難なこと、コードに作用 する伈力の正確な解析が困蜼なこと等の欠点のため、理 論的な疲労の研究目的にはやや不都合である。

Budd の報告している積極回転式屈曲ローラの試験機 は摩擦量を一定にする長所があるが、製作の困難、測定 値の分散が大になる等の短所がある。

Budd の派告には变動係数（標準偏差/平均値 \%) が 27\%であると報告しているが、我々の失験ではローラ回 転の場合の変動係数はレイシンコード10〜15\%、綿コー ド20〜25\%でめつた。屈曲摩擦の贸合はレイヨンコード は25〜30\%、綿コードは70〜90\%であつた。

故に磨耗現象は分散を增加せしめるるのと思わ机る。 Budd の積極回檕式では一定量の㦄耗が入つていらから 変動䋆数がやや大きいのであろろ。従つてこの点からい 之ば屈曲ローラを積極的比回転する必要はない。

\section{5. 結 論}

（1）レイヨンコードと綿コードとの疲労特性

レイヨンコードの)波労寿命は屈曲程度、屈曲と伸張と の組合ぜ、荷重等に対して甚だ敏感である。故にレイョ ンコードは使用条件のわずかの相違によつてもその寿命
に相当の差を生ずるものと予想される。レィョンコード に対して特饵腎い条件は大腲力で曲率の大きい曲げを受 ける場命である。

綿コードはレイヨンコード程条件に敏感でないから。 綿タイヤは比較的安定なるのと予想される。

\section{(2) 試験機の性能試験}

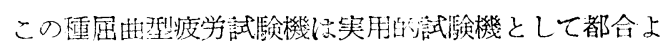

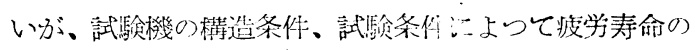
测定値は絶体値のみならず、比較値も甚しく変化するか

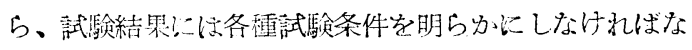
らない。灭一条件汽けの試驗で央用的な疲労抵抗の大小 を判断することは其げ后険であつて、各種条件の下訲試 験を行い綜合的飞断断しなけ和ばならない。

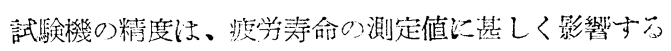
が、本実験では回侩速度はほとてど影響しなかつた。

\section{交献}

(1) Castricum. M, U. S. Pattent 1,923,296 (1933) Bradshaw W. H., A. S. T. M. No. 136, 13 (1945)

(2) Alten R. W. and Tegrotenhuis T. A., U. S. Pattent 2,157,092 (1936)

(3) Ray. F., U. S. Pattent 2,235,622 (1941) Mallory. G. D., U. S. Pattent 2,412,524

(4) Lessig E. T., U. S. Pattent 2,240,505 (1941)

( 5 ) Venable C.S., A. S. T. M. Bull. No. 136 , 17 (1945)

(6) W. E. Rosevcare and R. G. Waller, Text. Res. J. (1949-10) P. 633, (海外纎維技術交献集 1952-6)

( 7 ) M. W. Wilson, Text. Res. J. (1951-1) P. 47, (海外繊維技術交献集 1952-2)

(8) Chester B. Budd., Text. Res. J. (1951-3) P. 174,（海外㵶維技術交献集 1952-1） 